\title{
Neurotization of the Phrenic Nerve with Accessory Nerve for High Cervical Spinal Cord Injury with Respiratory Distress: An Anatomic Study
}

\author{
Solunum Sıkıntılı Yüksek Servikal Spinal Kord Yaralanması için Aksesuar \\ Sinir ile Frenik Sinir Nörotizasyonu: Anatomik bir Çalıșma
}

Ce WANG*, Ying ZHANG*, Tsai NICHOLAS, Guoxin WU, Sheng SHI, Yin BO, Xinwei WANG, Xuhui ZHOU, Wen YUAN

Second Military Medical University of China, Changzheng Hospital, Department of Orthopedics, Shanghai, China

${ }^{*}$ Ce Wang and Ying Zhang contribute equally to this manuscript.

Corresponding Author: Wen YUAN \& Xuhui ZHOU / E-mail: acorepie@126.com, yuanwenspine@163.com, zhouxuhuiczyy@126.com

\begin{abstract}
AIM: High cervical spinal cord injury is associated with high morbidity and mortality. Traditional treatments carry various complications such as infection, pacemaker failure and undesirable movement. Thus, a secure surgical strategy with fewer complications analogous to physiological ventilation is still required. We hope to offer one potential method to decrease the complications and improve survival qualities of patients from the aspect of anatomy. The purpose of the study is to provide anatomic details on the accessory nerve and phrenic nerve for neurotization in patients with high spinal cord injuries.
\end{abstract}

MATERIAL and METHODS: 38 cadavers (76 accessory and 76 phrenic nerves) were dissected in the study. The width, length and thickness of each accessory nerve and phrenic nerve above clavicle were measured. The distances from several landmarks on accessory nerve to the origin and the end of the phrenic nerve above clavicle were measured too. Then, the number of motor nerve fibers on different sections of the nerves was calculated using the technique of immunohistochemistry.

RESULTS: The accessory nerves distal to its sternocleidomastoid muscular branches were $1.52 \pm 0.32 \mathrm{~mm} \sim 1.54 \pm 0.29 \mathrm{~mm}$ in width, $0.52 \pm$ $0.18 \mathrm{~mm} \sim 0.56 \pm 0.20 \mathrm{~mm}$ in thickness and $9.52 \pm 0.98 \mathrm{~cm}$ in length. And the phrenic nerves above clavicle were $1.44 \pm 0.23 \mathrm{~mm} \sim 1.45 \pm 0.24 \mathrm{~mm}$ in width, $0.47 \pm 0.15 \mathrm{~mm} \sim 0.56 \pm 0.25 \mathrm{~mm}$ in thickness and $6.48 \pm 0.78 \mathrm{~cm}$ in length. The distance between the starting point of accessory nerve and phrenic nerve were $3.24 \pm 1.17 \mathrm{~cm}$, and the distance between the starting point of accessory nerve and the end of the phrenic nerve above clavicle were $8.72 \pm 0.84 \mathrm{~cm}$. The numbers of motor nerve fibers in accessory nerve were $1038 \pm 320 \sim 1102 \pm 216$, before giving out the sternocleidomastoid muscular branches. The number of motor nerve fibers in the phrenic nerve was 911 $321 \sim 1338 \pm 467$.

CONCLUSION: The accessory nerve and the phrenic were similar in width, thickness and the number of motor nerve fibers. And the lengths of accessory nerve were long enough for neuritisation with phrenic nerve.

KEYWORDS: Phrenic nerve, Accessory nerve, Anatomy, Spinal cord injury, Reconstruction

öz

AMAÇ: Yüksek servikal spinal kord yaralanması yüksek morbidite ve mortalite ile ilişkilidir. Geleneksel tedaviler enfeksiyon, kalp pili yetmezliği ve istenmeyen hareket gibi çeşitli komplikasyonlar taşır. Bu nedenle fizyolojik ventilasyona benzer ve daha az komplikasyonu olan güvenli bir cerrahi strateji gereklidir. Komplikasyonları azaltmak ve hastaların yaşam kalitesini artırmak için potansiyel bir yöntemi anatomik açıdan sunmak, yüksek spinal kord yaralanması olan hastalarda nörotizasyon için aksesuar sinir ve frenik sinirin anatomik ayrıntılarını sağlamak amaçlanmıştır.

YÖNTEM ve GEREÇLER: Çalışmada, 38 kadavranın (76 aksesuar ve 76 frenik sinir) diseksiyonu yapıldı. Klavikula üzerinde her frenik sinir ve aksesuar sinirin eni, boyu ve kalınlığı ölçüldü. Aksesuar sinirin çeşitli noktalarından klavikula üzerindeki frenik sinirin kökeni ve ucuna mesafeler ölçüldü. Daha sonra, immünohistokimya tekniği kullanılarak sinirlerin farklı bölümlerindeki motor sinir liflerinin sayısı hesaplandı.

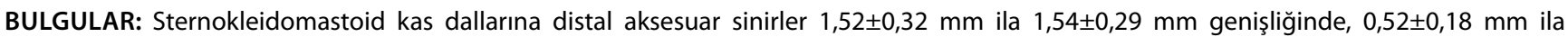

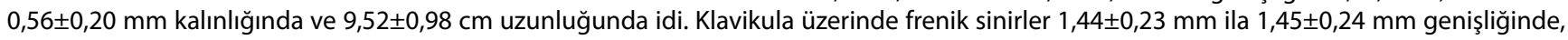
$0,47 \pm 0,15 \mathrm{~mm}$ ila $0,56 \pm 0,25 \mathrm{~mm}$ kalınlığında ve $6,48 \pm 0,78 \mathrm{~cm}$ uzunluğunda idi. Frenik sinir ile aksesuar sinirin başlangıç noktası arasındaki mesafe $3,24 \pm 1,17 \mathrm{~cm}$ idi, ve aksesuar sinirin başlangıç noktası ile klavikula üzerinde frenik sinirin ucu arasındaki mesafe $8,72 \pm 0,84 \mathrm{~cm}$ idi. Aksesuar sinirdeki motor sinir liflerinin sayısı sternokleidomastoid kas dalları ayrılmadan önce $1038 \pm 320$ ila $1102 \pm 216$ idi. Frenik sinirdeki motor sinir liflerinin sayısı $911 \pm 321$ ila $1338 \pm 467$ idi.

SONUÇ: Aksesuar sinir ve frenik sinirin genişlik, kalınlık ve motor sinir lif sayısı benzerdi. Aksesuar sinirin uzunluğu frenik sinir ile nörotizasyon için yeterince uzundu.

ANAHTAR SÖZCÜKLER: Frenik sinir, Aksesuar sinir, Anatomi, Spinal kord yaralanması, Rekonstrüksiyon 


\section{INTRODUCTION}

Due to advances in the transportation and building industry recently, the incidence of upper cervical spinal cord injury (SCl) caused by motor vehicle accident and falls has been rising. About $5 \%$ of upper cervical spinal cord injury patients lose respiratory function and become dependent on ventilators. The quality of life suffers as a result of decreased mobility and linguistic function. Moreover, the complications of mechanical ventilation such as mechanical obstruction and pulmonary infection always predispose them to high mortality $(4,5,13,15,26,27)$. Phrenic nerve pacing (PNP) overcomes aforementioned disadvantages to some extent, and simulates a natural negative pressure mechanism $(2,6)$. It improves mobility range of patients and allows for normal speech. However PNP still has the potential risk of nerve injury, undesirable movement, pacemaker failure, infection and complications of surgery and does not allow optimal physiological control of respiration $(4-6,19,29)$. Thus, a secure surgical strategy with less complications following high spinal cord injury is still required (22). Polentes et al. evaluated functional respiratory recovery by recording diaphragm and phrenic nerve activity after olfactory ensheathing cell (OEC) transplantation following cervical cord hemisection. While the transplanted ipsilateral phrenic activity achieved $57.5 \%$ of the control with elimination of contralateral influence via contralateral $C_{1}$ section (16), which is not optimal considering potential complications. Similarly, Li et al studied recovery of respiratory function by OEC transplantation and thought many possible factors may contribute to breathing improvement. They were unsure of positive contribution of OEC (1). On the contrary, nerve transfer procedures are routinely performed for severe brachial plexus injury (BPI). Microsurgeons have achieved satisfactory improvement in muscle power, movement of joint and preventing deformity $(1,3,7,14,21,23)$, which provides a basis for utilizing autologous nerve transfer in recovery of respiratory function following high cervical injury (9). Gauthier et al. studied unilateral recurrent laryngeal nerve-phrenic nerve anastomosis for improving respiratory function of rats after high cervical spinal cord injury. They found that rats could survive without asphyxiation even if the spinal cord at C2 was transected completely 5 months after nerve transfer (8). Gauthier et al. and Vinit et al. proposed that neuroplasty and remodeling have taken place to control respiratory function after nerve transfer $(8,9,25)$. However, the recurrent laryngeal nerve (RLN) is functionally important and intimately associated with vagus nerve. Severe complications would arise after division of RLN. The accessory nerve has often been utilized for repair of the brachial plexus $(3,7,14,21)$. Being one of the cranial nerves, it remains functional after spinal cord injury and can be an ideal donor nerve for transposition to phrenic nerve to improve respiratory function in patients with high cervical spinal cord injury.

Research on neurotization of the phrenic nerve by accessory nerve to improve respiratory function of patients with high cervical spinal cord injury is rare according to our literature review. Data are particularly scarce in correlative experimental animal and human studies. Thus, our aim was to provide anatomic information that may aid in the development of this potential procedure to improve the quality of life in these patients.

\section{MATERIAL and METHODS}

38 formalin-fixed cadavers (33 males, 5 females. Department of Anatomy, Qiqihaer Medical University), choline acetyl transferase monoclonal antibody (1:200), PV-9000 pathologic image analysis system, Vernier caliper (accuracy is $0.02 \mathrm{~mm}$ ).

\section{Measurements and Anatomic Relations of AN and PN}

38 formalin-fixed cadavers ( 33 males, 5 females) underwent dissection for this study. The AN was dissected carefully from jugular foramen to lateral border of sternocleidomastoid and medial border of trapezius. Supraclavicular segment of PN was separated along surface of scalenus anterior to thoracic inlet. 1) We measured major trunk of AN from the level of hyoid to the intersection of $\mathrm{AN}$ and medial border of trapezius. This length it was then further divided into 5 segments from $A_{1}$ to $A_{5}$ as depicted in Figure 1. The width and thickness of three segments $\left(A_{1}, A_{3^{\prime}}, A_{4}\right)$ were measured by a vernier caliper. The change in width and thickness was noted in order to find best transposition location. Similarly, we measured major trunk of PN from its origin to where it meets the superior border of clavicle. This length it was divided into 3 segments from $C_{1}$ to $\mathrm{C}_{3}$ as in Figure 1. The width and thickness of three segments $\left(C_{1}, C_{2}, C_{3}\right)$ were measured, and the change in width and thickness was also noted for best transposition location. 2) We then measured the distances from the main trunk of AN at the level of hyoid to the origin of PN and its distal end above the clavicle.

\section{Immunohistochemical Staining and Number of Motor Fibers}

The specimens of $A N$ and $P N\left(A_{1}-A_{4^{\prime}}, C_{1}-C_{3}\right)$ from 10 cadavers were selected. Those chosen segments were stained by streptavidin-peroxidase method. The motor fibers of AN and PN were positively expressed after applying monoclonal antibody neurofibrin and choline acetyl transferase respectively. The positively expressed motor fibers were accepted for quantitative analysis via PV-9000 pathologic image analysis system.

\section{RESULTS}

\section{Anatomy and Measurement of AN}

AN often gives out 2 5 branches to the sternocleidomastoid at its superior 1/4 1/3 medial border after leaving the jugular foramen. The major trunk of AN then converges with $\mathrm{C} 2$ or C3 or both of them. Thereafter, about $7.89 \%$ of AN descend through sternocleidomastoid, while $92.11 \%$ of AN continue to descends along deep surface of sternocleidomastoid. We measured length, width and thickness of every segment of AN. The measurements are shown in Table I. AN emerges from the posterior border of sternocleidomastoid, where have 7.5 9 $\mathrm{cm}$ away from the clavicular terminal of sternocleidomastoid, 
and enters trapezius about $1.5 \mathrm{~cm}$ medial to midclavicular line. The location is relatively fixed and can be found easily. We also found AN spiraled through the connective tissue and the true length at stretch exceed the apparent length. The true length measured averages $9.52 \pm 0.98 \mathrm{~cm}$ and linear length averaged $8.18 \pm 1.04 \mathrm{~cm}$.

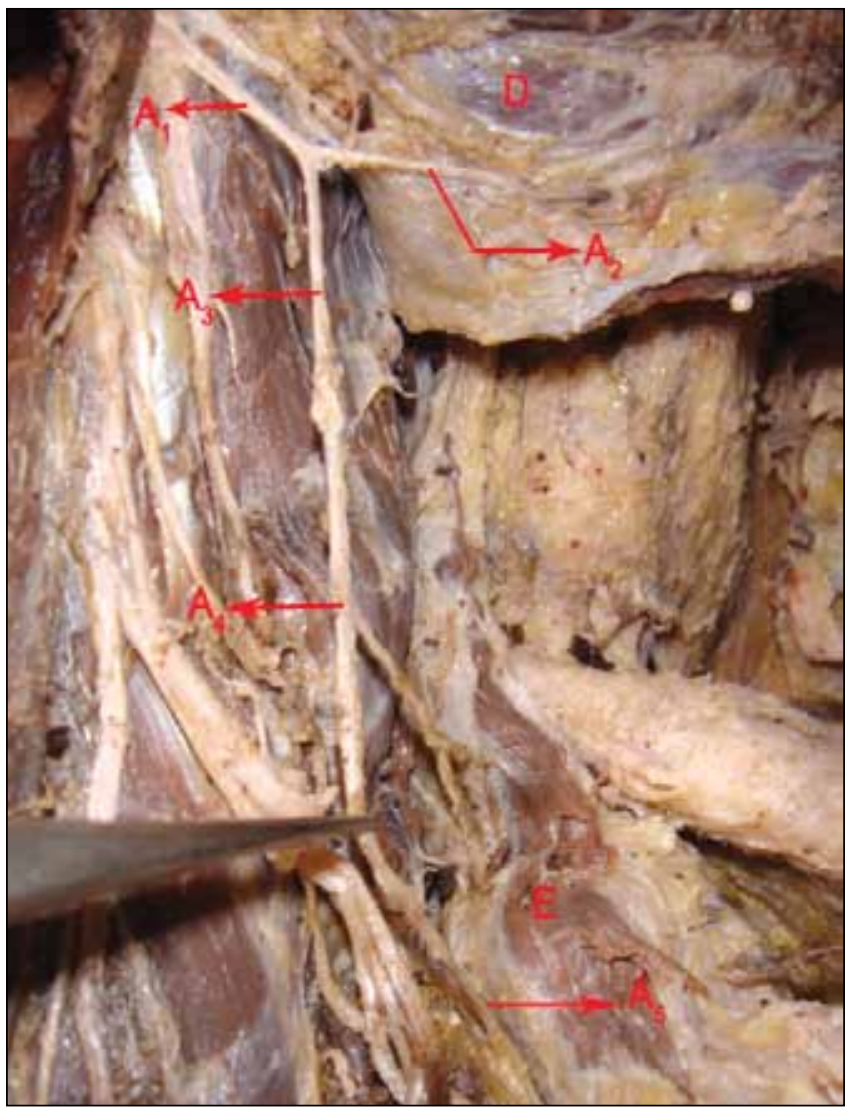

\section{Anatomy and Measurement of PN}

The phrenic nerve, after being formed by the convergence of the anterior roots of $\mathrm{C} 3 / 4 / 5$ at the superior part of the anterior scalenus, descends along the superficial aspect of the anterior scalenus and enters the thoracic cavity via the thoracic inlet.

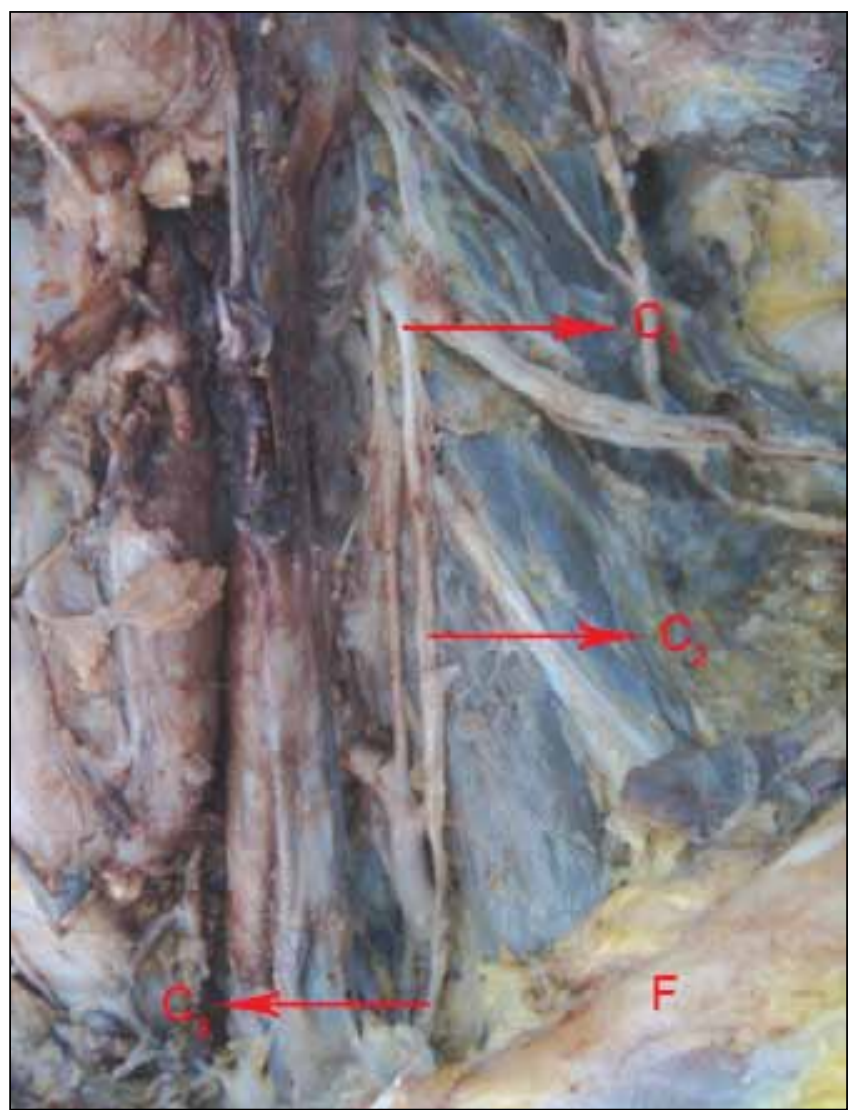

Figure 1: A1: AN at level of hyoid bone; A2: sternocleidomastoid branch of AN; A3: the trunk of AN after giving out A2; A4: the trunk of AN in posterior cervical triangle; A5: the trunk of AN at intersection of AN and trapezius; C1: initial segment of PN; C2: middle segment of PN above clavicle; C3: segment above intersection of PN and clavicle; D: sternocleidomastoid; E: trapezius; F: clavicle.

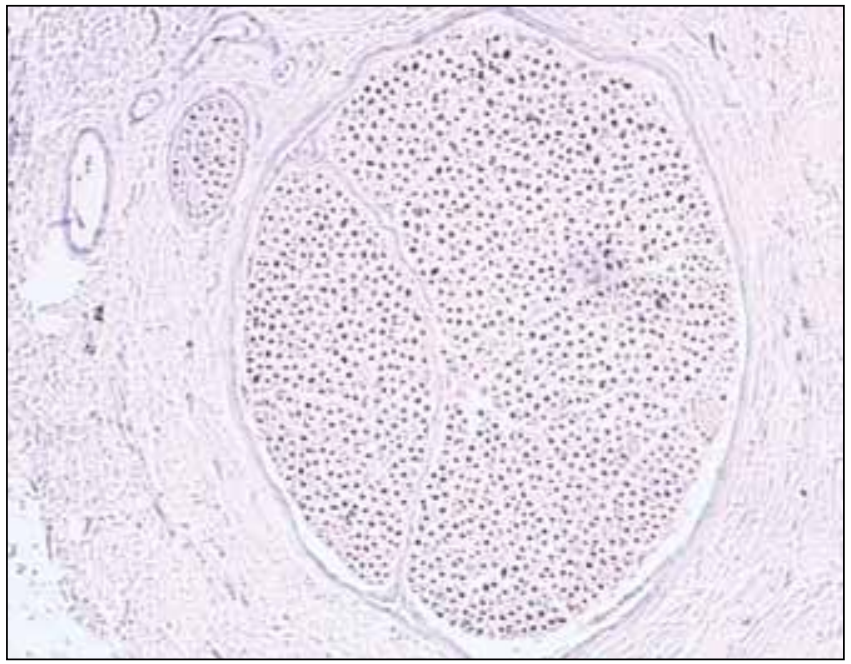

Figure 2: Motor neurofibers of AN.

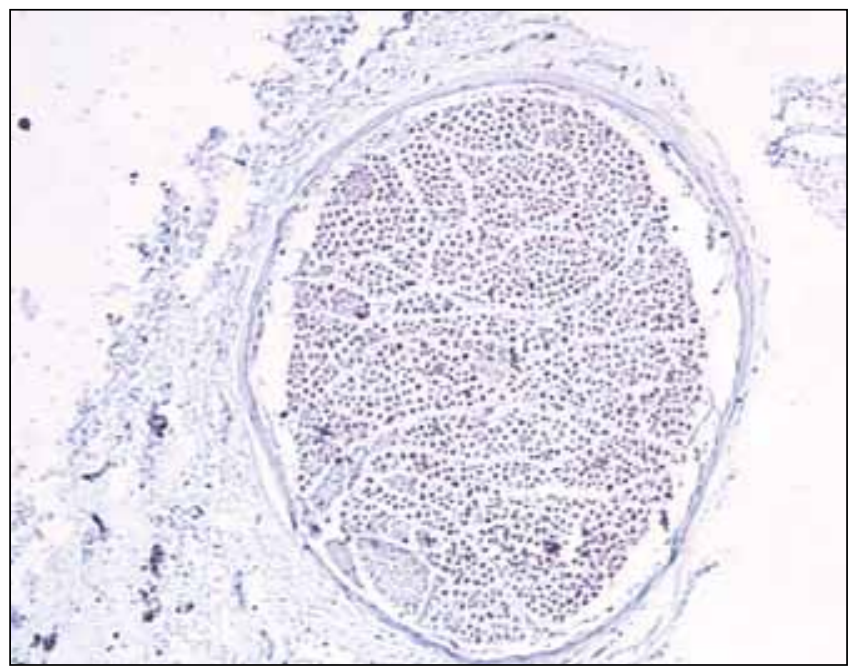

Figure 3: Motor neurofibers of PN. 
Table I: The Width, Thickness and Length of the Accessory Nerve and Phrenic Nerve

\begin{tabular}{|l|c|c|c|c|c|c|}
\hline$(\mathrm{mm})$ & $\mathbf{C}_{1}$ & $\mathbf{C}_{2}$ & $\mathbf{C}_{3}$ & $\mathbf{A}_{1}$ & $\mathbf{A}_{3}$ & $\mathbf{A}_{4}$ \\
\hline Width & $1.44 \pm 0.27$ & $1.44 \pm 0.23$ & $1.45 \pm 0.24$ & $1.74 \pm 0.39$ & $1.54 \pm 0.29$ & $1.52 \pm 0.32$ \\
\hline Thickness & $0.56 \pm 0.25$ & $0.47 \pm 0.15$ & $0.47 \pm 0.16$ & $0.59 \pm 0.22$ & $0.52 \pm 0.18$ & $0.56 \pm 0.20$ \\
\hline
\end{tabular}

Table II: Contents of Motor Neurofibra in Different Segments of the Accessory Nerve and Phrenic Nerve

\begin{tabular}{l|c|c|c|c|c|c|c} 
& $\mathbf{A}_{1}$ & $\mathbf{A}_{2}$ & $\mathbf{A}_{3}$ & $\mathbf{A}_{4}$ & $\mathbf{C}_{1}$ & $\mathbf{C}_{2}$ & $\mathbf{C}_{3}$ \\
\hline $\begin{array}{l}\text { Motor } \\
\text { neurofibra }\end{array}$ & $1933 \pm 377$ & $963 \pm 434$ & $1038 \pm 320$ & $1102 \pm 216$ & $911 \pm 321$ & $1007 \pm 367$ & $1338 \pm 467$
\end{tabular}

We dissected PN till the superior border of clavicle and measured the length of the supraclavicular segment of PN, the length of which was $6.48 \pm 0.78 \mathrm{~cm}$, The data of width and thickness were obtained respectively at origin of $P N\left(C_{1}\right)$, most distal part of PN just above clavicle $\left(C_{3}\right)$ and midpoint between the two $\left(C_{2}\right)$. The results are presented in Table $I$.

\section{Relationship of AN and PN}

Anastomosis without strain is mandatory for success. Therefore we investigated the shortest and longest distances of transposition from AN to PN. The distances from AN at the level of the hyoid bone to the origin of $\mathrm{PN}$ and to the supraclavicular end of PN were $3.24 \pm 1.17 \mathrm{~cm}, 8.72 \pm 0.84 \mathrm{~cm}$, respectively.

\section{Number of Motor Fibers in Different Segments of AN and PN}

The contents of every segment of $\mathrm{AN}$ and PN were measured via immunohistochemical method (Figure 2,3). There were no statistically significant differences in contents of motor neurofibers in $C_{1}, C_{2}, A_{3}$ and $A_{4}$ (Table II) $(p=0.218$, SNK test SPSS 13.0).

\section{DISCUSSION}

The diaphragm plays a significant role in eupnoea, which is also the major power of respiratory movement. Ventilatory capacity (VC) induced by the contraction of the diaphragm approximates 3/4 4/5 in eupnoea. Auxiliary respiratory muscles such as intercostal muscles and abdominal muscles can hardly sustain the normal respiration alone $(10,15)$. If diaphragmatic muscles can be controlled via the accessory nerve after its transfer to the phrenic nerve, high spinal cord injury patients may acquire autonomous respiration. Spinal accessory nerve, which is widely utilized for reconstruction surgery in brachial plexus and birth palsy $(3,7,21)$, is derived from the lateral region of the anterior horn in spinal cord and below the boundary between the medulla oblongata and spinal cord. The spinal accessory nerve originates between the denticulate ligaments and the dorsal rootlets of the spinal nerves (24). Saylam et al. via observing anatomy of 49 specimens from 27 human cadavers found that the most inferior root of spinal contribution to AN derives from C3 segment, in 42.9\%; from C5 segment in $16.3 \%$, and it was never seen to derive below the C6 segment (18). Soo et al. proposed that motor neurofibers to the middle and upper parts of trapezius came more from AN, while the lower third came from the cervical plexus $(20)$. Kierner $(11,12)$ found that the nerve supply to the descending part of trapezius muscle consisted of a single fine branch of the spinal accessory nerve, whereas the transverse and ascending parts were innervated by both the spinal accessory nerve and the trapezius branches of the cervical plexus. Wang, $S$ et al. reported, 3 4 branches from the accessory nerve at the supraclavicular level terminated at the trapezius. Electrophysiology and muscle power examinations confirmed that the lower trapezius was affected the most and $90 \%$ of the upper and middle trapezius could maintain grade 3 or more muscle power after AN was divided at infraclavicle level (30). Therefore, the nerves entering the trapezius include both accessory nerve and branches of C2 C4. Useful function of trapezius is therefore retained after the anastomosis of the accessory nerve to the phrenic nerve. Interestingly, Satomi et al. found that the neuronal cell bodies of the spinal AN have a very similar topographic localization to the phrenic nucleus in the anterior ventral horn of cats (17), which can aid neuroplasty and remodeling of neurons of accessory nerve following nerve transfer.

In this anatomical study, we found that the dimensions of the major trunk of AN (width: $1.52 \pm 0.32 \mathrm{~mm} \sim$ $1.54 \pm 0.29 \mathrm{~mm}$, thickness: $0.52 \pm 0.18 \sim 0.56 \pm 0.20 \mathrm{~mm}$ ) after its stemocleidomastoideus branch were similar to that of PN (width: $1.44 \pm 0.23 \mathrm{~mm} \sim 1.45 \pm 0.24 \mathrm{~mm}$, thickness: $0.47 \pm 0.15 \mathrm{~mm} \sim 0.56 \pm 0.25 \mathrm{~mm}$ ). The distance between AN at the level of hyoid and the origin of PN was $3.24 \pm 1.17 \mathrm{~cm}$, and that between accessory nerve at the level of hyoid and supraclavicular end of PN was $8.72 \pm 0.84 \mathrm{~cm}$. The mean length of AN was $9.52 \pm 0.98 \mathrm{~cm}$, which is sufficiently long for its transfer to PN.Thus, it is possible to perform transposition of accessory nerve to $\mathrm{PN}$ in order to restore autonomous respiratory function anatomically. Additionally, we quantified the motor fibers of PN and AN by immunohistochemical method. We found the quantity of motor neurofibers after AN gives out the stemocleidomastoideus branch is 1038 $\pm 320 \sim 1102 \pm 216$, and that of phrenic nerve is $911 \pm 321 \sim 1338 \pm 467$. There are no significant differences in contents of motor neurofibers in $C_{1}, C_{2}, A_{3}$ and $A_{4}$ statistically ( $P=0.218$, SNK test SPSS 13.0). The quantity of motor neurofibers in distal segment of $A N$ and proximal segment PN are comparable. Therefore, the 
accessory nerve can provide sufficient motor neurofibers for promoting regeneration of phrenic nerve. Moreover, good clinical results have been obtained through the use of AN for neurotization of the facial, suprascapular, axillary, radial, and musculocutaneous nerves (14).

\section{CONCLUSION}

The phrenic nerve has better capacity for regeneration than other nerves (28). Furthermore, injury of spinal cord differs from rupture of peripheral nerves in that axon degeneration and atrophy of skeletal muscle are relatively slow, which provides a sound tissue basis for nerve transposition. Thus, our study has confirmed the feasibility of PN neurotization utilizing AN to restore respiratory function in high spinal cord injury patients in terms of anatomy and immunohistochemistry. Meanwhile, relevant animal research is being undertaken and has achieved early positive results. We hope this procedure can provide a secure, long-term sustainable and physiological respiratory movement for patients with high cervical spinal cord injury.

\section{REFERENCES}

1. Amr SM, Moharram AN: Repair of brachial plexus lesions by end-to-side side-to-side grafting neurorrhaphy: Experience based on 11 cases. Microsurgery 25:126-146,2005

2. Baer GA, Talonen PP, Hakkinen V, Exner G, Yrjölä H: Phrenic nerve stimulation in tetraplegia. A new regimen to condition the diaphragm for full-time respiration. Scand J Rehabil Med 22:107-111, 1990

3. Bertelli JA, Ghizoni MF: Nerve root grafting and distal nerve transfers for C5-C6 brachial plexus injuries. J Hand Surg Am 35:769-775,2010

4. Brown R, DiMarco AF, Hoit JD, Garshick E: Respiratory dysfunction and management in spinal cord injury. Respir Care 51:853-868; discussion 69-70, 2006

5. DiMarco AF: Phrenic nerve stimulation in patients with spinal cord injury. Respir Physiol Neurobiol 169:200-209, 2009

6. DiMarco AF: Restoration of respiratory muscle function following spinal cord injury. Review of electrical and magnetic stimulation techniques. Respir Physiol Neurobiol 147:273287, 2005

7. El-Gammal TA, El-Sayed A, Kotb MM: Surgical treatment of brachial plexus traction injuries in children, excluding obstetric palsy. Microsurgery 23:14-17, 2003

8. Gauthier P, Baussart B, Stamegna JC, Tadié M, Vinit S: Diaphragm recovery by laryngeal innervation after bilateral phrenicotomy or complete C2 spinal section in rats. Neurobiol Dis 24:53-66, 2006

9. Gauthier P, Rega P, Lammari-Barreault N, Polentes J: Functional reconnections established by central respiratory neurons regenerating axons into a nerve graft bridging the respiratory centers to the cervical spinal cord. J Neurosci Res 70:65-81, 2002

10. Glenn WW, Hogan JF, Phelps ML: Ventilatory support of the quadriplegic patient with respiratory paralysis by diaphragm pacing. Surg Clin North Am 60:1055-1078, 1980
11. Kierner AC, Zelenka I, Burian M: How do the cervical plexus and the spinal accessory nerve contribute to the innervation of the trapezius muscle? As seen from within using Sihler's stain. Arch Otolaryngol Head Neck Surg 127:1230-1232, 2001

12. Kierner AC, Zelenka I, Heller S, Burian M: Surgical anatomy of the spinal accessory nerve and the trapezius branches of the cervical plexus. Arch Surg 135:1428-1431, 2000

13. Levine $S$, Nguyen T, Taylor N, Friscia ME, Budak MT, Rothenberg P, Zhu J, Sachdeva R, Sonnad S, Kaiser LR, Rubinstein NA, Powers SK, Shrager JB: Rapid disuse atrophy of diaphragm fibers in mechanically ventilated humans. $N$ Engl J Med 358:1327-1335, 2008

14. Midha R: Nerve transfers for severe brachial plexus injuries: $A$ review. Neurosurg Focus 16:E5, 2004

15. National Spinal Cord Injury Statistical Center: Spinal cord injury. Facts and figures at a glance. J Spinal Cord Med 28:379380, 2005

16. Polentes J, Stamegna JC, Nieto-Sampedro M, Gauthier P: Phrenic rehabilitation and diaphragm recovery after cervical injury and transplantation of olfactory ensheathing cells. Neurobiol Dis 16:638-653, 2004

17. Satomi H, Takahashi K, Aoki M, Kasaba T, Kurosawa Y, Otsuka $\mathrm{K}$ : Localization of the spinal accessory motoneurons in the cervical cord in connection with the phrenic nucleus: An HRP study in cats. Brain Res 344:227-230, 1985

18. Saylam CY, Orhan M, Aktan Ikiz ZA, Uçerler H, Zileli M: Connection types between the spinal root of the accessory nerve and the posterior roots of the C2-C6 spinal nerves. Surg Radiol Anat 31:419-423, 2009

19. Series $F$, Verin E, Similowski T: Impediment in upper airway stabilizing forces assessed by phrenic nerve stimulation in sleep apnea patients. Respir Res 6:99, 2005

20. Soo KC, Guiloff RJ, Oh A, et al. Innervation of the trapezius muscle: A study in patients undergoing neck dissections. Head Neck 12:488-495, 1990

21. Sulaiman OA, Kim DD, Burkett C, Della Rovere GQ, Westbury G: Nerve transfer surgery for adult brachial plexus injury: A 10year experience at Louisiana State University. Neurosurgery 65:A55-62, 2009

22. Tator $\mathrm{CH}$ : Strategies for recovery and regeneration after brain and spinal cord injury. Inj Prev 8 Suppl 4:IV33-36, 2002

23. Terzis JK, Kostopoulos VK: The surgical treatment of brachial plexus injuries in adults. Plast Reconstr Surg 119:73e-92e, 2007

24. Tubbs RS, Pearson B, Loukas M, Shokouhi G, Shoja MM, Oakes WJ: Phrenic nerve neurotization utilizing the spinal accessory nerve: Technical note with potential application in patients with high cervical quadriplegia. Childs Nerv Syst 24: 1341-1344, 2008

25. Vinit S, Boulenguez P, Efthimiadi L, Stamegna JC, Gauthier P, Kastner A: Axotomized bulbospinal neurons express C-Jun after cervical spinal cord injury. Neuroreport 16:1535-1539, 2005

26. Watson PJ, Hixon TJ: Effects of abdominal trussing on breathing and speech in men with cervical spinal cord injury. J Speech Lang Hear Res 44:751-762, 2001 
27. Winslow C, Rozovsky J: Effect of spinal cord injury on the respiratory system. Am J Phys Med Rehabil 82:803-814, 2003

28. Zhang CG, Ma JJ, Terenghi G, Mantovani C, Wiberg M: Phrenic nerve transfer in the treatment of brachial plexus avulsion: An experimental study of nerve regeneration and muscle morphology in rats. Microsurgery 24:232-240, 2004
29. Zimmer MB, Nantwi K, Goshgarian HG: Effect of spinal cord injury on the respiratory system: Basic research and current clinical treatment options. J Spinal Cord Med 30:319-330, 2007

30. Wang SF, Zhang GM, Gu YD, Zhang LY, Zhao X: A clinical study of spinal accessory nerve transfer for the repair of suprascapular nerve to restore the impaired abduction function of the shoulder following avulsion injury of the brachial plexus [in Chinese]. Chin J Orthop 20: 594-597, 2000 